\title{
鼓索・舌神経切除によるウサギ茸状乳頭の 形態的变化に関する電子顕微鏡的研究
}

\author{
村木祐孝 \\ 九州歯科大学大学院歯学研究科口腔外科学第 1 専攻（指導：福田仁一教授） \\ 九州歯科大学口腔解剖学第 2 講座（指導：嶋村昭辰教授）
}

平成 5 年 12 月 24 日受理

\section{Ultrastructural Study on Morphological Changes of Rabbit Fungiform Papillae Following Neurectomy of Chorda-Lingual Nerves \\ Yukoh Muraki}

First Department of Oral Surgery (Director: Prof. Jinichi Fukuda)

Second Department of Oral Anatomy (Director: Prof. Akitatsu Shimamura)

Kyusyu Dental College, Kitakyushu, Japan

The epithelia of rabbit fungiform papillae and filiform papillae were studied by electron microscopy. Further, filiform changes observed in the dorsal epithelium of fungiform papillae after chorda-lingual neurectomy were studied by scanning electron microscopy; the state of keratinization of the epithelium was observed by transmission electron microscopy; and the findings were compared with those in the epithelium of normal filiform papillae.

The surface of fungiform papillae was relatively smooth, and the dorsal epithelium was covered by a thin keratin layer with no keratohyalin granules.

In filiform papillae, the nature of keratinization was quite different between the epithelial cell layers on the anterior and posterior aspects of the papillae. On the anterior aspect, epithelial cells contained many keratohyalin granules, were nucleated to the topmost layer, and formed a soft keratin layer, showing a strong tendency toward parakeratosis. On the posterior aspect, in contrast, the cytoplasm of epithelial cells was rich in ribosomes and tonofibrils, but few keratohyalin granules were noted. The superficial cells had no nuclei or cell organelles and showed true keratinization, forming a hard keratin layer.

After chorda-lingual neurectomy, taste buds in fungiform papillae degenerated, and marked progression of keratinization was observed in the dorsal epithelium of many fungiform papillae 1 week after denervation. The keratin layer on the dorsal aspect of these papillae was thickened, and the papillae were characteristically pointed as in filiform papillae and curved toward the pharynx. These changes became more notable with time, and the fungiform papillae were difficult to distinguish from surrounding filiform papillae by scanning electron microscopy 6 months after denervation.

In the dorsal epithelium of fungiform papillae showing marked changes, transmission 
electron microscopy showed a pseudokeratotic layer occasionally containing condensed nuclei in the anterior aspect of the papillae but a keratin layer without nuclei or cell organelles in the posterior aspect. The ultrastructural examination of markedly degenerated fungiform papillae revealed a dual keratinization pattern similar to that in the epithelium of filiform papillae. Keratohyalin granules were observed in fungiform papillae showing marked keratinization. The appearance of keratohyalin granules not observed in normal fungiform papillae showing only mild keratinization suggests that they play a role in keratinization of fungiform papillary epithelium.

Key words : Fungiform papilla/Denervation/Filiform-like fungiform papilla/Rabbit/ Electron microscopy

\section{緒言}

von Vintschgau ら (1877)1) がウサギを用いて，舌 咽神経切断後の葉状乳頭味蕾の変化を観察して以来，哺 乳動物の葉状乳頭ならびに有郭乳頭の味蕾の形態および 機能の維持には, 味神経 (舌咽神経) の存在が不可欠で あり, 味神経を切除すると味蕾は変性・消失し, 神経の 再生にとすなって味蕾も再生することが報告されてきた

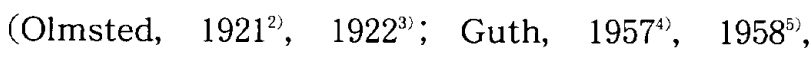
$1963^{6)}, 1971^{7>}$; Farbman, 1969 ${ }^{8}$; Fujimoto ら, $1970^{9)}$; Kennedy, 1972 ${ }^{10)}$; Oakley, 1974 ${ }^{113}$; 近藤 $\left.1983^{12)}\right)$.

このことは, 神経がインパルスの伝導以外に, 支配領 域の細胞や組織の形態を維持させるための, 神経栄養的 因子を有することを示唆するものと考えられる.

一方，茸状乳頭は顔面神経に由来する鼓索神経上，三 叉神経に由来する舌神経により，二重に支配されている ことが知られている（Farbman ら，1978 ${ }^{13)}$; Zahm ら, $1985^{(4)}$; Whitehead ら，1985 $\left.{ }^{15)}\right)$ 。この茸状乳頭におい ては, 鼓索・舌神経切除後も味蕾は消失しないとの報告

(Whitehead, 1987'16); Riddle ら, 1988 $8^{17}$; Hård af Segerstad $ら, 1989^{18}$; Kinnman $ら, 1991^{19}$; Oliver

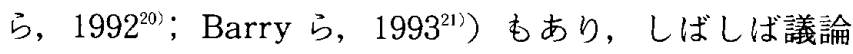
の対象となってきた。

近年, Ganchrow ら $(1989)^{222}$ はラットで, 中島 $(1988)^{23)}$ ，Nakashima ら $(1990)^{24)}$ は成熟したウサ ギで, 鼓索·舌神経を長期にわたって切除した状態にし ておくと，茸状乳頭の味蕾が消失するとともに，味蕾の 消失した茸状乳頭自体にも顕著な形態的変化が起こり, 系状乳頭様構造を示すようになることを報告した，その 後,この様な現象に関して，いくつかの報告（Oakley

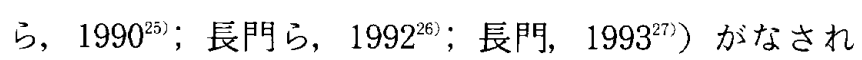
てきた。この中で長門ら (1992) ${ }^{26)}$ は，ラットを用いた 出生後間もない時期での鼓索・舌神経切除が, 茸状乳頭 の完全な糸状乳頭化を引き起こすことを報告し，咠状乳 頭が鼓索·舌神経の神経栄養因子により誘導·維持され る, 特殊に形態変化した系状乳頭である可能性を示唆し た、しかしながら, 系状乳頭様に变化した茸状乳頭背面 上皮の角化の椂相を, 微細構造的に検索したものはな い.

本研究では，この様な鼓索·舌神経を切除した後に， 茸状乳頭背面上皮に現れる現象を詳細に観察する上同時 に，この現象を正常な糸状乳頭上皮にみられる角化の様 相之, 微細構造的に比較検討した。

\section{材料ならびに方法}

実験動物には体重 $3 \mathrm{~kg}$ 前後の雄の成熟ウサギ（日本白 色種）を用いた。麻酔は塩酸キシラジン（セラクター ル ${ }^{\circledR}$, Bayer $) 5 \mathrm{mg} / \mathrm{kg}$, 塩酸ケタミン（ケタラール ${ }^{\circledR}$, 三共） $0.7 \mathrm{ml} / \mathrm{kg}$ を大腿部に筋注併用することによって 行った. 麻酔後, ウサギを実験台に仰卧位に固定し，才 トガイ部から咽頭部にかけて剃毛，ヨード及び $70 \% エ$ タノールで消毒したのち, エピネフリン含有 $2 \%$ リド カイン $1.8 \mathrm{ml}$ 用いて局所麻酔を行った。咽頭部の正中 にオトガイ下部から舌骨部に至る約 $7 \mathrm{~cm}$ の皮膚切開を加 え, 顎二腹筋及び顎舌骨筋を露出, 顎舌骨筋正中部より 右側方を正中と平行に切離し, 鼓索・舌神経を露出し た，同様にして左側の鼓索·舌神経を露出し，これらの 神経を微小外科用器具及び手術用顕微鏡を用いて周用組 織より剝離した，続いて右側の鼓索·舌神経のみを約 5 mm切除し，軸索の再生を防止することを目的に両断端を それぞれ前後に折り返し結禁した（図 1)。創部は抗生 
Fu.P
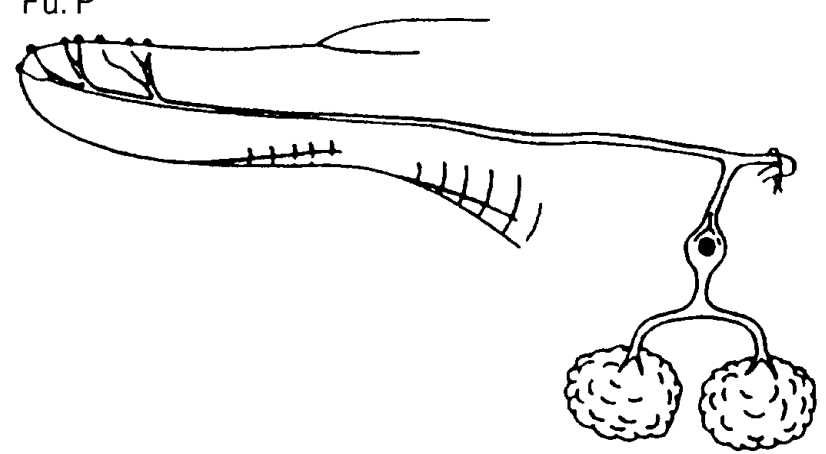

図 1 ウサギ舌前方部の感覚神経支配と神経切除部位を示す

$\mathrm{V}$ : 三叉神経 VII : 顔面神経 L : 舌神経

$\mathrm{CT}$ ：鼓索神経 Sm. G : 顎下腺 Fu. P : 茸状乳頭

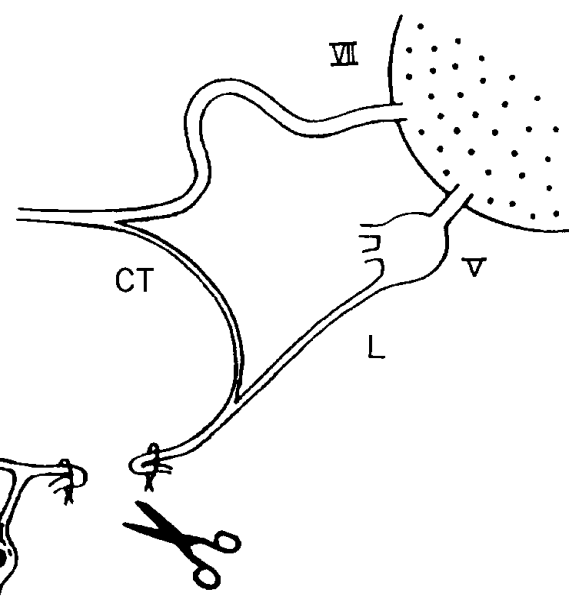

Sm.G

剤で洗浄後，筋層·皮膚縫合を行った。実験期間は神経 切除後 2,4 日, $1,2,4,8$ 週, 6 力月間とし, 各経日 4 頭, 計 28 頭を用いた。

各実験期間飼育したウサギは, 鼓索·舌神経切除時と 同様の方法により麻酔後, 両側外頸静脈を切断し, 両側 総頸動脈より血液抗凝固剤添加生理食塩液にて脱血を 行った後， $0.1 \mathrm{M}$ リン酸（pH 7.3）で緩衝した $2 \%$ パ ラホルムアルデヒドと $2.5 \%$ グルタールアルデヒドとの 混合液にて灌流固定を行った。固定後直ちに舌を全摘 し, 各経日 2 頭, 計 14 頭の舌を, 神経切除側の茸状乳 頭を含む $2 \times 2 \times 2 \mathrm{~mm}$ のブロックに細切した，細切した ブロックは同固定液で 6 時間浸漬固定を行った後， $1 \%$ オスミウム酸 (Millonig, 1961 $1^{28}$ ) で 2 時間後固定を行 い，上昇エタノール系列にて脱水，プロピレンオキサイ ドで置換した後, エポキシ樹脂 (Luft, 1961 ${ }^{29}$ ) に包埋 した。組織はガラスナイフを装着した Porter-Blum MT2B ウルトラミクロトームにて $1 \mu \mathrm{m}$ の切片とし, $1 \%$ トルイジンブルー (Björkman, 1962 $\left.2^{30}\right)$ で染色し た後, 光学顕微鏡的観察に供した. さらにダイアモンド ナイフを用いて $90 \mathrm{~nm}$ の超薄切片を作製後, コロジオ

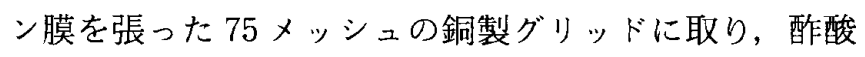
ウラン (Tandler, 1990 $0^{311}$ ) ならびに鉛 (Sato, 1968 ${ }^{322}$ ) による電子染色を施し, カーボン蒸着を行った後, JEM-1200 EX П 透過型電子顕微鏡にて観察した.

一方, 残りの各経日 2 頭, 計 14 頭の舌は, 走査電顕
的観察に供した. 舌をアルデヒドで固定した後, タンニン 酸及びオスミウム酸にて導電染色を行い（Murakami, $\left.1973^{33}\right)$, エ夕ノール脱水, T-ブチルアルコールに置換 後, 凍結乾燥を施し (Inoue ら, 1988 $8^{34}$ ), 白金パラジ ウム蒸着を行った後, 日立 $\mathrm{S}-530$ 走查型電子顕微鏡に て観察した。

\section{結 果}

I. 正常茸状乳頭ならびに糸状乳頭の組織構造 ウサギの舌は舌背の中央部に存在する臼歯間隆起に よって舌背前部と舌背後部に区別することができるが, 茸状乳頭は舌背前部にのみ観察され, 舌背後部には認め られない，また，茸状乳頭は前方に向かうに従ってその 数を増し, 舌尖部で特に密集する. 舌背前部を走查電顕 で観察すると，舌前方部には，ほほ同様の円錐形を呈し た糸状乳頭が分布している，系状乳頭の先端は，すべて 咽頭方向に向けて傾斜している。この様な系状乳頭に介 在して茸状乳頭が観察される. 茸状乳頭の表面は比較的 平滑で，その中央部付近には数力所味孔が開口するのが 認められる(図2).

茸状乳頭を矢状断切片にて観察すると, 乳頭固有層に はよく発達した二次乳頭の形成がみられる，乳頭上皮は 乳頭側面においては表層まで核が認められる錯角化を示 すが, 乳頭背面では菲薄な角質層へと移行する(困 3 ). 透過電顕で観察すると, 乳頭側面では, 基底層および有 

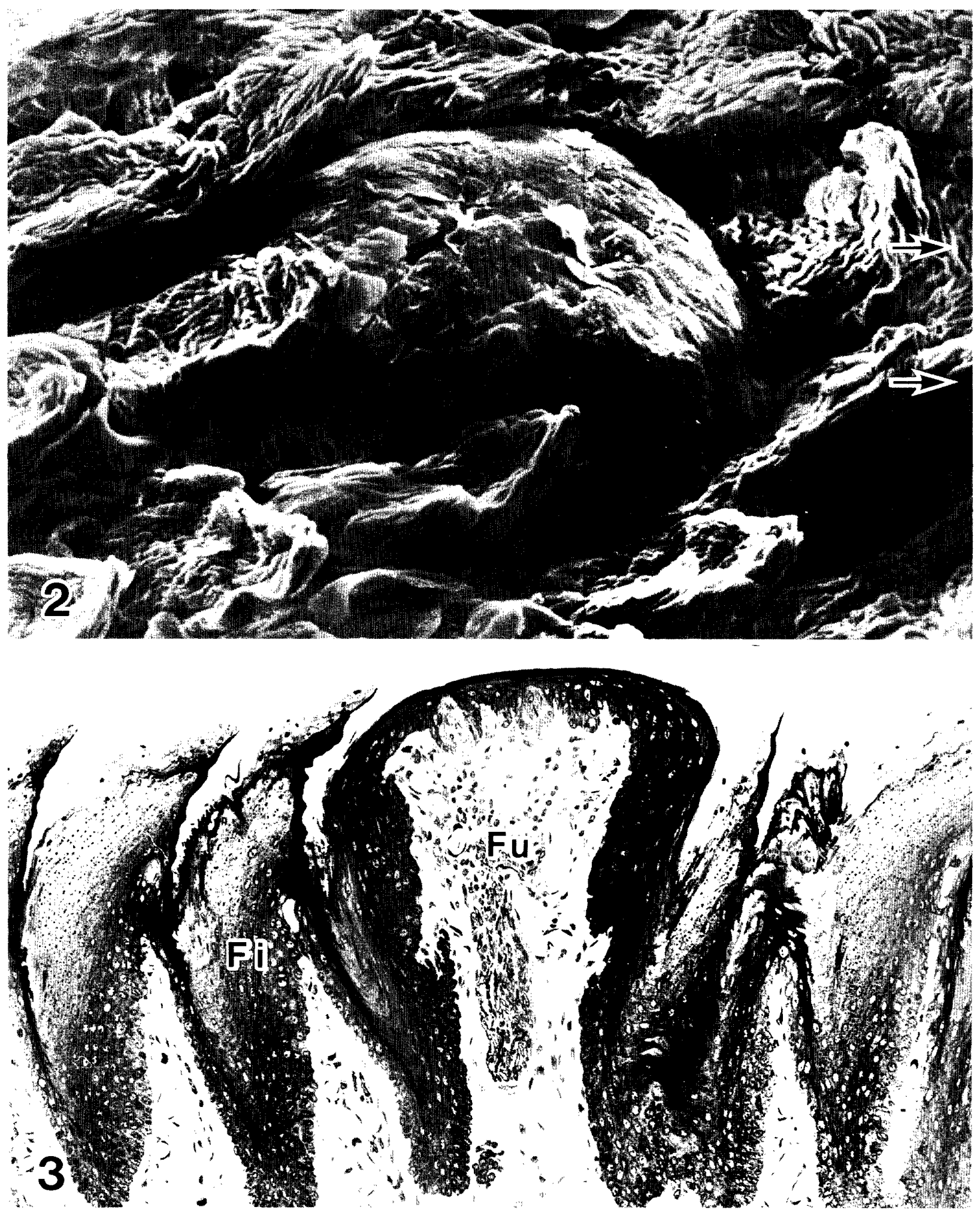

図 2 舌; 背前部の走查電顕写真

系状乳頭の先端はすべて咽頭方问（矢盺）に向けて傾斜しており，茸状乳頭はこれら糸状乳頭に介在して存在する $\times 350$ 図 3 舌背㓩部糸状乳頭 $(\mathrm{Fi})$ および茸状乳頭 $(\mathrm{Fu})$ の矢状断光顕写真

苜状乳頭側面の上皮は表層まで核が認められる錯角化傾向を示すが，草状乳頭背面では菲薄な角質層へ上移行する $\times 200$ 

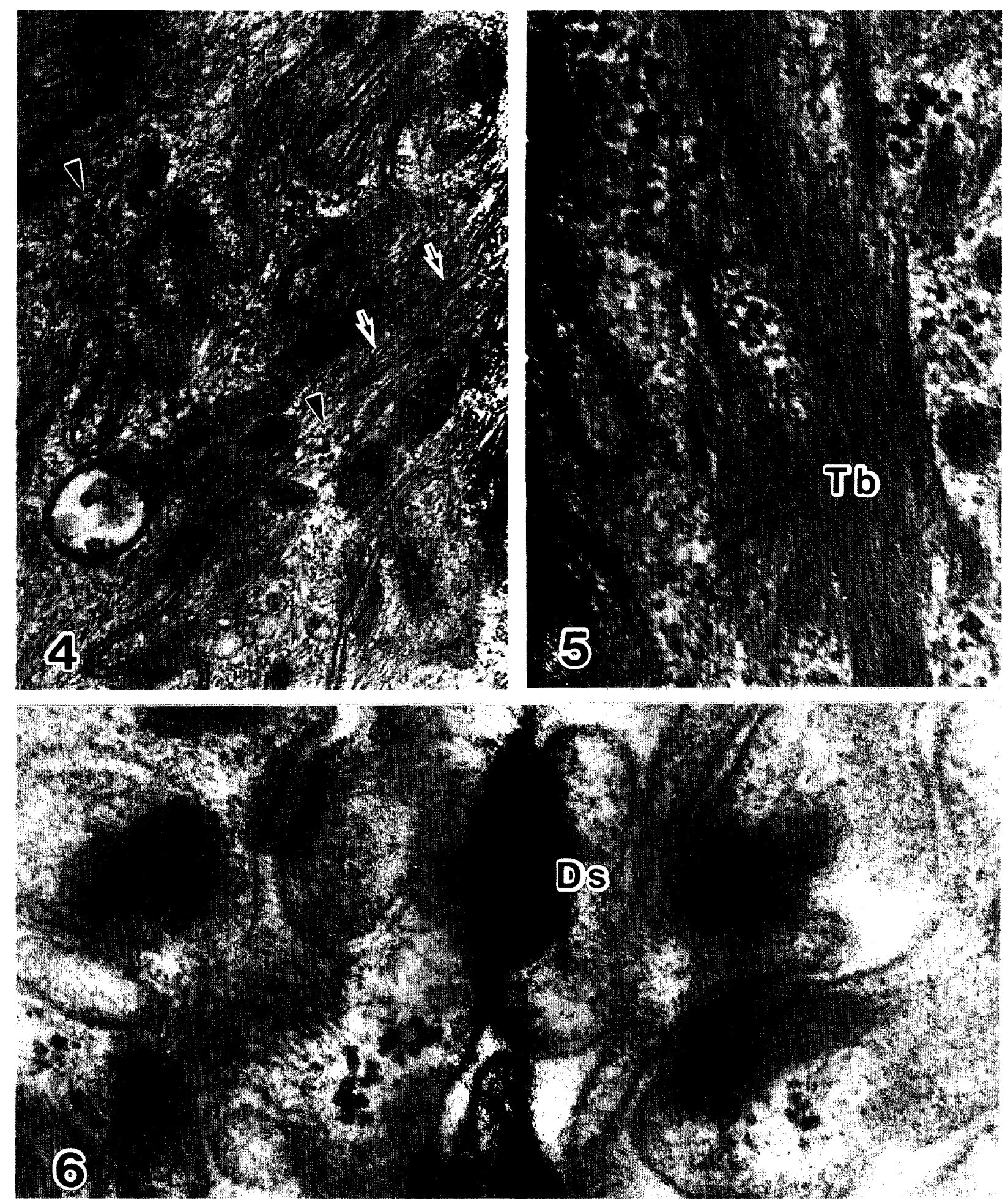

図 4-6 茸状乳頭側面の透過電顕写真

図 4 遊離リボゾーム（失じり）や多数の張フィラメント（矢印）が観祭される $\times 50000$

図 5 張フィラメントは集束して張原線維 $(\mathrm{Tb})$ を形成する $\times 89000$

図6 各細胞はよく発達した嵌命やデスモゾーム（Ds）によって瓦いに強く結合する $\times 80000$ 

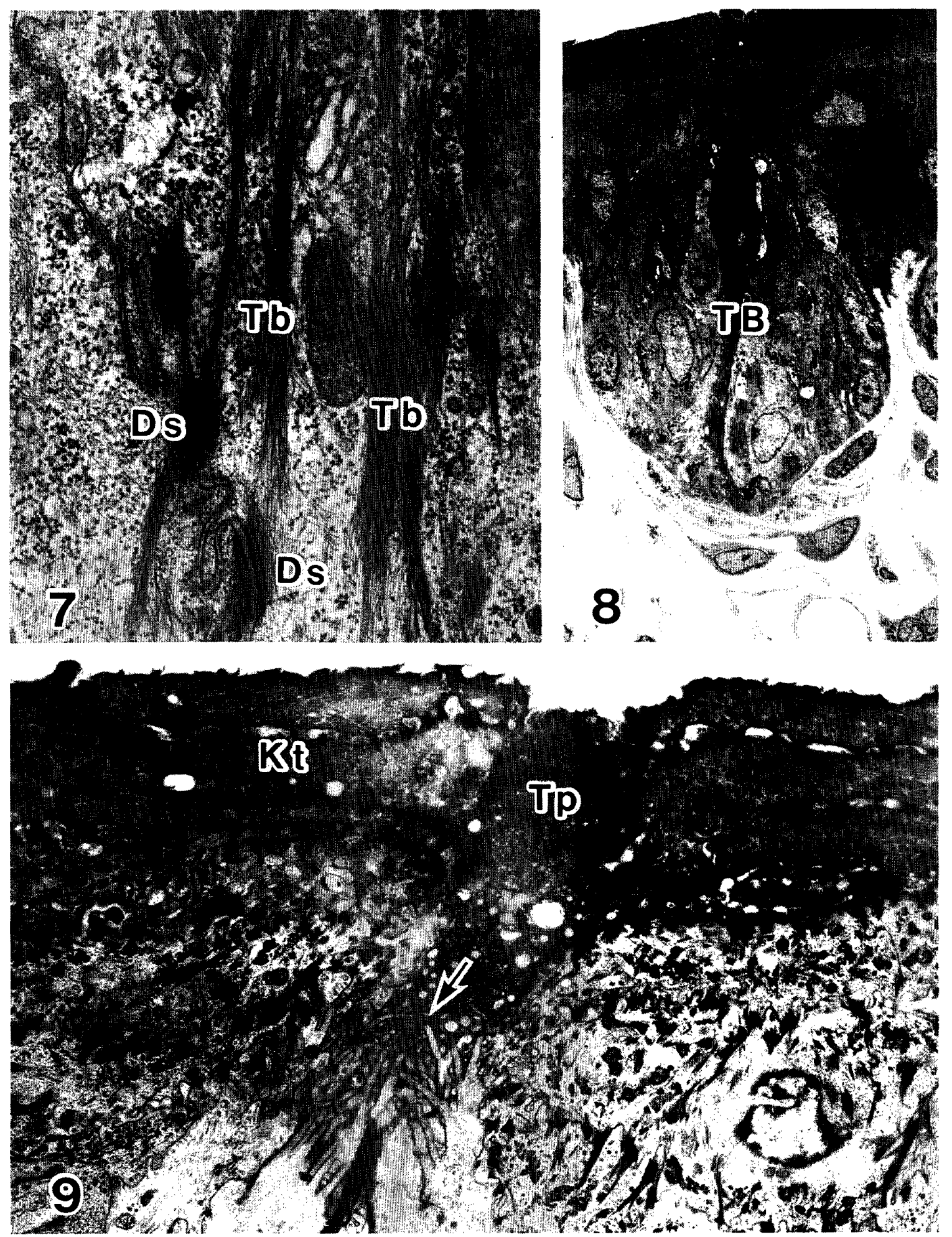

図 7-9 苜状乳頭背面の透過電顕写真

図 7 デスモゾーム（Ds）と連続するよく発達した張原線維（Tb）が観察される $\quad \times 30000$

図 8 乳頭背面上皮内には味蕾 (TB) 汃認められる $\times 1000$

図9 味孔（Tp）周囲上皮の透過電顕写真

乳頭背面は電子密度の高い扁平化した角質細胞 (Kt) によって被われる

矢印：味毛 $\times 7000$ 
棘層上皮の細胞質内には, 遊離リボゾームや多数の張 フィラメントが認められる(図 4)。これら張フィラメ ントは中間層にいくに従って, 次第に集束し, 張原線維 を形成する（図 5).さらに中間層から表層になると， 細胞は著しく扁平化するが, 各細胞はよく発達した嵌合 やデスモゾームによって，互いに結合するのが観察され る(図 6)。一方, 乳頭背面の基底層㧍よび有棘層の上 皮細胞内には，デスモゾームと連続するよく発達した張 原線維が観察される（図 7)。角質層になると, 細胞は 著しく扁平化し, 核は認められない (図 9). 茸状乳頭 背面の上皮内には，2４個の味蕾が認められ（図 8), 味孔を通して口腔環境亡接触する (図 9 ).

系状乳頭を矢状断にて観察する之，その先端はすべて 咽頭方向に傾斜している。系状乳頭内部では, よく発達 した固有層が乳頭先端近くまで入り込み，二次乳頭を形 成している. 系状乳頭の上皮は，これら二次乳頭の前方 部にみられる細胞層と, 後方部にみられる細胞層とで は，角化の様相が著しく異なっている，すなわち系状乳 頭前面部上皮は，最表層まで核か認められる錯角化を示 すが，乳頭後面部は，表層が角質層によって被われる真 性角化上皮加らなる（図 10).

糸状乳頭前面の上皮を透過電顕で観察する之, ほとん どの上皮細胞内にケラトヒアリン顆粒の分布が認められ る.ケラトヒアリン顆粒は上皮表層に向かうに従って, それぞれの顆粒が融合し徐々に大きさを増すが（図 11)，最表層近くになると突然消失する．上皮深層の細 胞は，隣接する細胞之複雑な嵌合や上く発達したデスも ゾームによって, 密接して結合する（図 12）。しかし表 層にいくに従って, 細胞間隙は著しく拡大する。このよ うなところでは, デスモゾームの発達は悪い（図 13）。 ケラトヒアリン顆粒の周囲では遊離リボゾーム, 張フィ ラメントあるいはミトコンドリアが豊富に観察される (図 12).

一方, 糸状乳頭後面の上皮は, トルイジンブルーに著 しく濃染する厚い角質層を有することを特徵とする（図 10). 透過電顕で観察すると, 後面上皮の細胞質内は遊 離リボゾームや張原線維が多数観察されるが, ケラトヒ アリン顆粒はほとんど認めら扎ない（図 14）。上皮表層 は，核ならびに細胞内小器官を欠く電子密度の高い角質 層によって被われている（図 15）.

II. 鼓索·舌神経切除後の苗状乳頭の形態的变化

鼓索·舌神経を切除することによって，ほとんどの苗 状乳頭内味蕾は早期より变性し始め, 神経切除 4 日後で は一部の茸状乳頭で, 連続切片においても味蕾を確認す
ることができない(図 16).

神経切除 1 週間後になると, 走查電顕的にあ多くの耳 状乳頭で味孔の消失および乳頭表面の角化亢進が認めら れ, 表面形態は粗造となる (図 17). 光顕的には, 味蕾 の完全に消失した乳頭では上皮表層の角質層が肥厚し， 乳頭の表面は平滑さを失う。このような変化は, 乳頭中 央部付近で特に著しい（図 18）。

神経切除 2 週間後で最む変化の著しい咠状乳頭表面を 走査電顕で観察すると, 乳頭背面の平滑さは失われ, 細 胞が剝離脱落しつつある所見も観察される（図 19）. 矢 状断切片では, 乳頭背面の上皮は, 厚い角質層を伴って 円錐状に尖鋭化し，その先端は僅加に咽頭側へ傾斜する 傾向がみられる。特に乳頭の咽頭側すなわち後面では, 糸状乳頭の後面上皮と同様に, トルイジンブルーに濃染 する角質層が著明に観察される（図 20）。

神経切除 4 週間後になると, 系状乳頭様に变化した茸 状乳頭では, 乳頭背面中央部が著しく突出し, 咽頭側に 向かって先端が尖鋭化するのが観察される（図 21）。 ま た希にではあるが，先端が咽頭側ではなく，舌縁方向へ 向かって尖鋭化しているものも観察される（図 22）. 矢 状断切片で観察すると, 茸状乳頭背面の角質層の肥厚 は, 乳頭の尖鋭化した部分より乳頭後面にかけて著しく 発達しているが，乳頭前面では，次第に錯角化層へと移 行する (四 23)。このような茸状乳頭を透過電顕的に観 察すると, 乳頭の前面においては, 最表層付近でむ一部 の細胞で濃縮した核の残存する錯角化傾向を示す（図 24). 一方, 乳頭の後面は核や細胞内小器官をほとんど 失った，電子密度の高い角質細胞によって被われている (図 25).

神経切除 8 週間後になると, 変化の著しい咠状乳頭に 扔いては, 乳頭背面はさらに突出し, 咽頭側に傾斜した 乳頭先端部はさらに尖鋭化する。このように一部の咠状 乳頭は周用系状乳頭之非常に類似した形態的特徵を示 し, しばしば走査電顕的にも系状乳頭との識別が困難で ある（図 26）。矢状断切片で観察すると,トルイジンブ ルーに濃染する角質層はさらに厚みを増し，乳頭後面部 では，ほぼ全域にわたって角質層により被われるが，乳 頭前面部では錯角化層屯認められる（四 27）。

神経切除 6 力月後の舌表面を走査電顕で観察すると, 糸状乳頭は正常舌とほぼ同様の組織構造を示すが, 舌側 縁部および舌尖付近を除いて，系状乳頭の間に茸状乳頭 を確認することはできない（図 28）。しかしながら，矢 状断切片にて観察すると, 固有層の形態学的特徴によっ て, さらに系状乳頭様に変化の進んだ咠状乳頭を識別す 

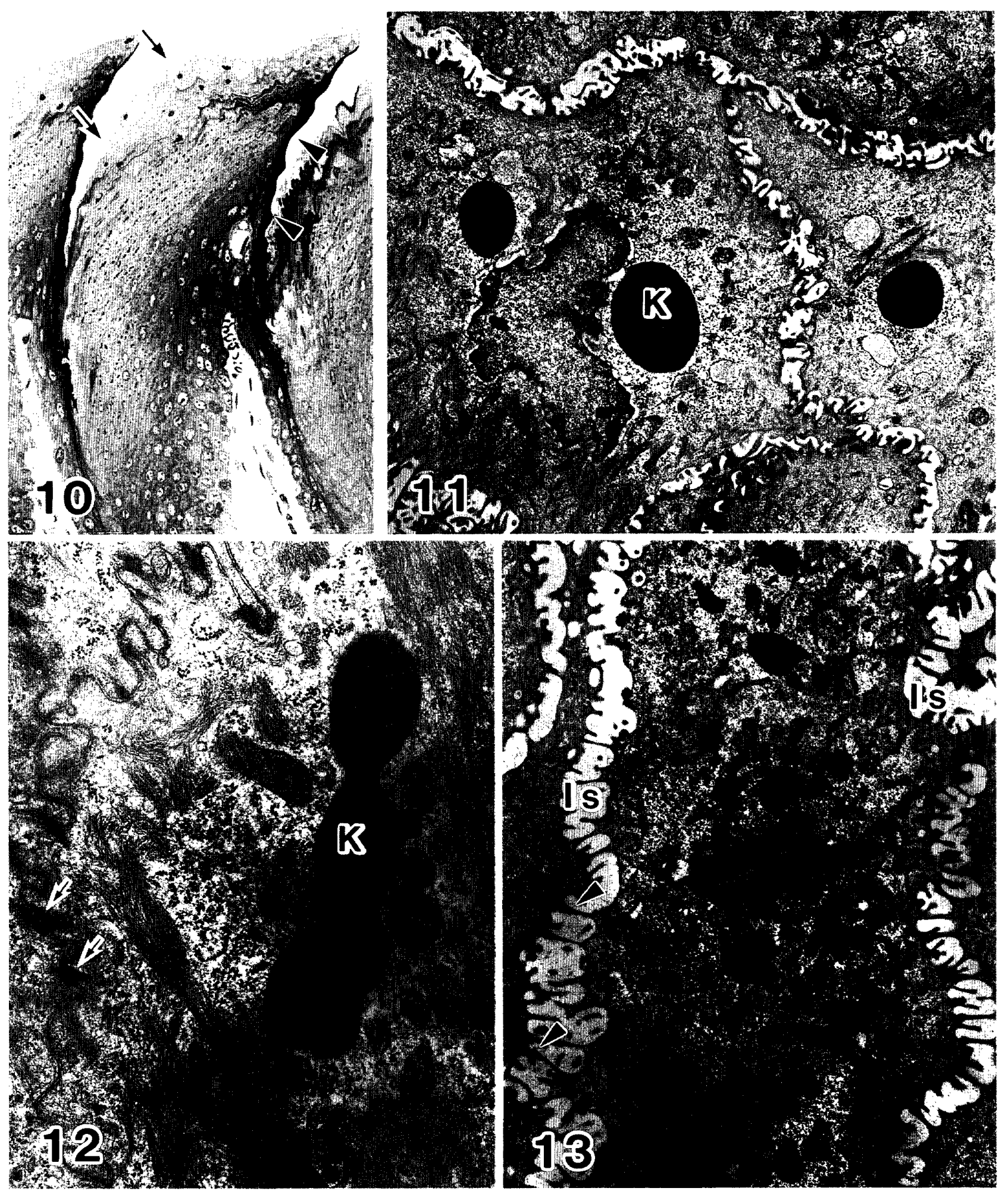

図10 正常系状乳頭の矢状断光顕写真

系状乳頭前面部上皮（矢印）は錯角化を示すが，乳頭後面部（矢じり）は真性角化上皮からなる $\times 310$

図11-13 系状乳頭前面上皮の透過電顕写真

図11 中間層の細胞内にはケラトヒアリン顆粒 $(\mathrm{K})$ が認められる $\times 4000$

図12 深層では，隣接する上皮細胞間には複雑な嵌合とよく発達したデスモゾーム（矢印）が観察される $\times 20000$

図13 表層付近では，細胞間隙（Is）は拡大し，わずかに細胞間橋（矢じり）によって互いに結合する 


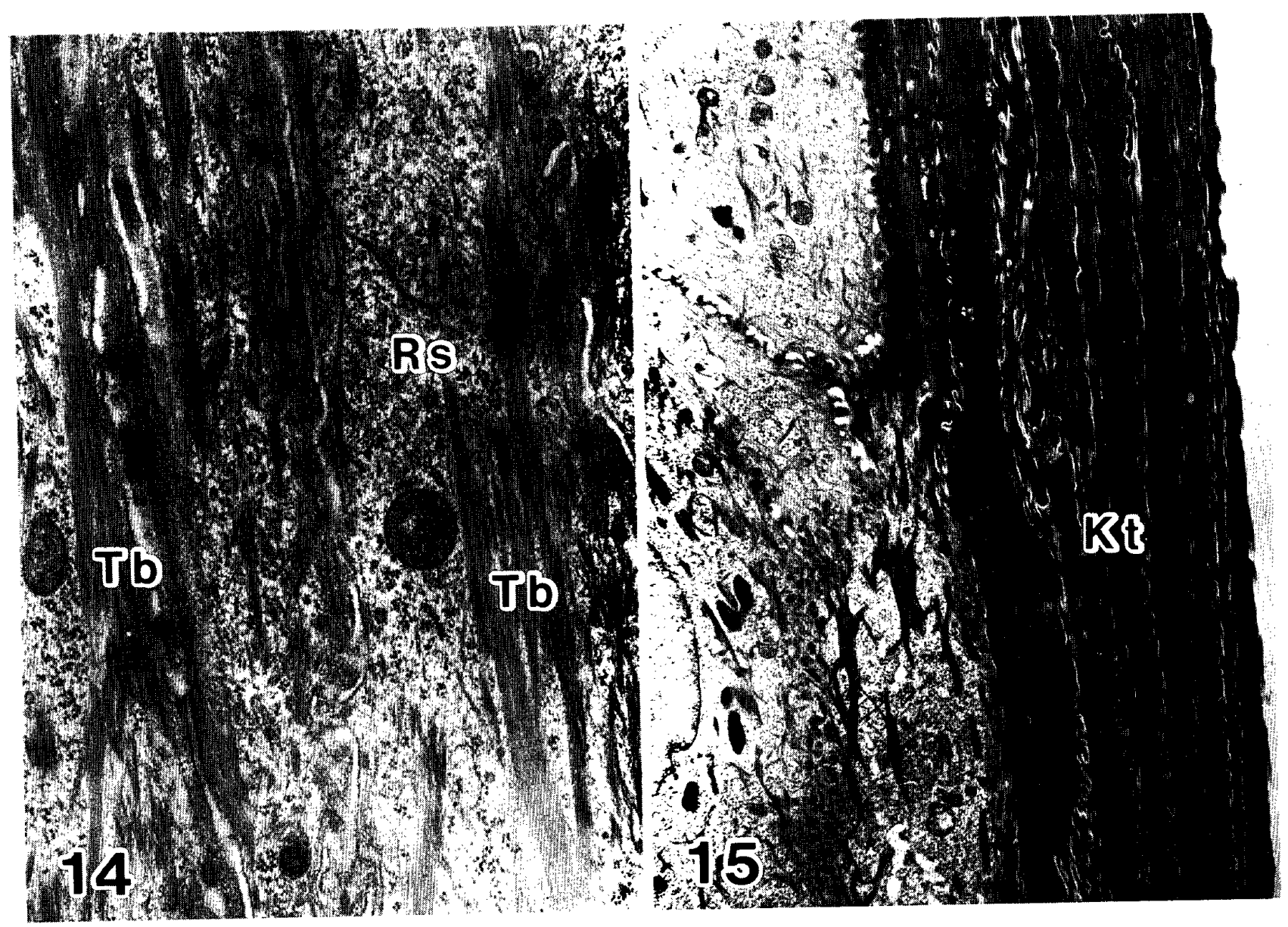

図14-15 糸状乳頭後面上皮の透過電顕是真

細胞啠内には多数の遊離リボゾーム（Rs）や張原線維（Tb）が観察される $\times 20000$

図15 上皮表層は核ならびに細胞内小器官を欠く電子密度の高い角質層 $(\mathrm{Kt})$ によって被われる

ることができる.このように变化した咠状乳頭は乳頭の 幅径が著しく縮小しており，光顕的にも周囲系状乳頭と 非常に類似した組織像を示す。すなわち，乳頭前面部の 上皮は糸状乳頭前面におけるのと類似した錯角化を示す のに対し，乳頭後面部では上皮表層が角質層からなる真 性角化の所見を呈している（図 29）。

変化した苗状乳頭の前面を透過電顕的に観察すると, 前面上皮の細胞層は, 先端付近を除いて錯角化傾向を示 し，所々に濃縮した核の残存する細胞を認める（図 30). 張フィラメントは細胞質内で集束せず, 散在して いる(図 31)。細胞間隙は, 表層の広い範囲において著 しく開大し，デスモゾームの発達も悪い（図 30)。一 方, 後面上皮細胞の細胞質内は, 多数の張原線維とリボ ゾームによって満たされている. 張原線維は扁平化した 細胞の長軸に沿って並行な走行を示す (図 33). 細胞間 隙は表層に向かうに従って嵌合を失い, 徐々に開大す る. 表層の角質細胞は電子密度が非常に高く, 核をはじ めとした細胞内小器官は消失している(図 34)。また乳
頭の前面および後面上皮の細胞質内には，しばしばケラ トヒアリン顆粒が出現するのが認められる（図 32, $35)$.

\section{考察}

哺乳動物の茸状乳頭は, 顔面神経由来の鼓索神経と, 三叉神経由来の舌神経によって二重支配を受けているこ とが知られている。 その中で, 鼓索神経は味蕾内に終末 する味神経として, また舌神経は味蕾周囲の上皮内に終 末するとともに, 固有層に存在する機械受容神経終末装 置を形成し，体性感覚をつかさどる神経として，その機 能が推測されてきた，最近になってラットの口蓋に分布 する味蕾 (corpuscular bodies) は，三叉神経によっ て支配されているとの報告（Liem ら，1990 355) あある が, 三叉神経が直接味覚情報の伝達に関与するという見 解は，一般に否定されている(山本ら，1993 ${ }^{36)}$ ).

有郭乳頭や葉状乳頭において, 味神経（舌咽神経）を 切除すると味蕾は変性し，ついには完全に消失するが， 

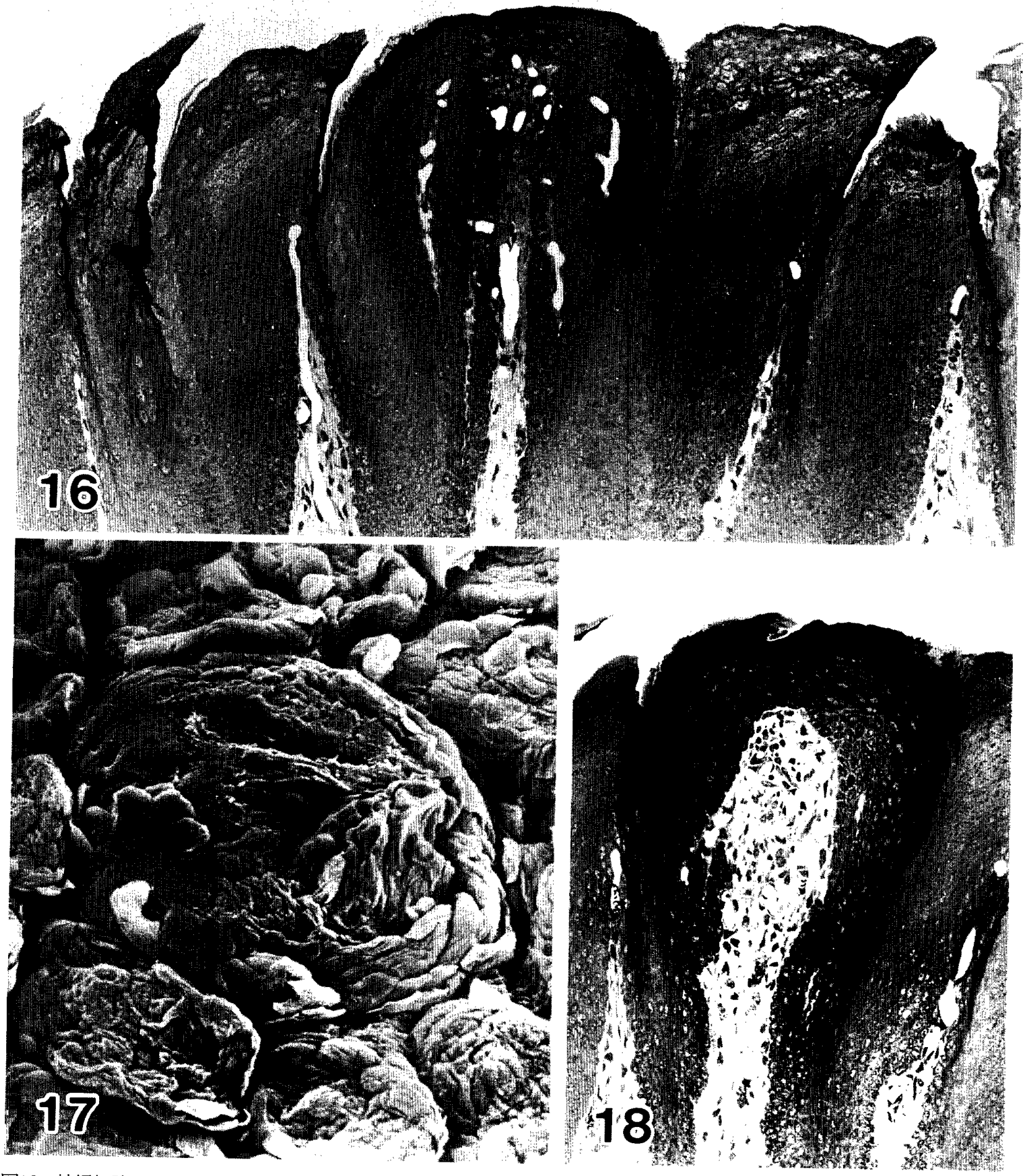

図16 神経切除 4 日後の茸状乳頭の矢状断光顕写真 $\quad \times 200$

図17 神経切除 1 週間後の茸状乳頭の走査電顕写真

味孔は消失し乳頭表面の角化が元進するのが観察される

図18 神経切除 1 週間後の咠状乳頭の矢状断光顕写真

上皮表層の角質層は肥厚し，乳頭の表面は平滑さを失う $\times 250$ 

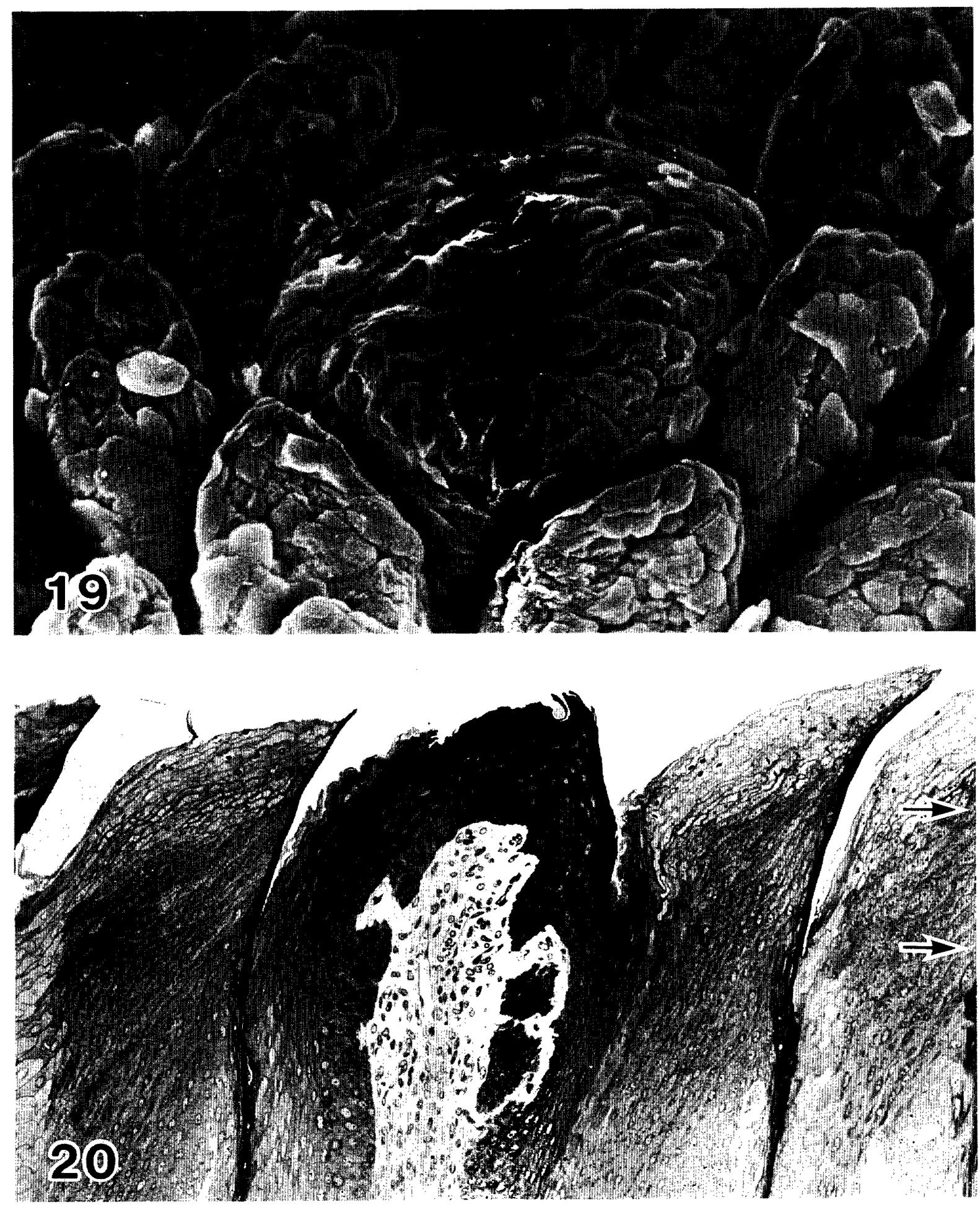

図19 神経切除 2 週間後の苜状乳頭の走查電顕写真 $\quad \times 350$

図20 神経切除 2 週間後の苜状乳頭の矢状断光顕写真

乳頭の先端は僅かに咽頭側 (矢印) 一傾斜する傾向を示す $\times 320$ 


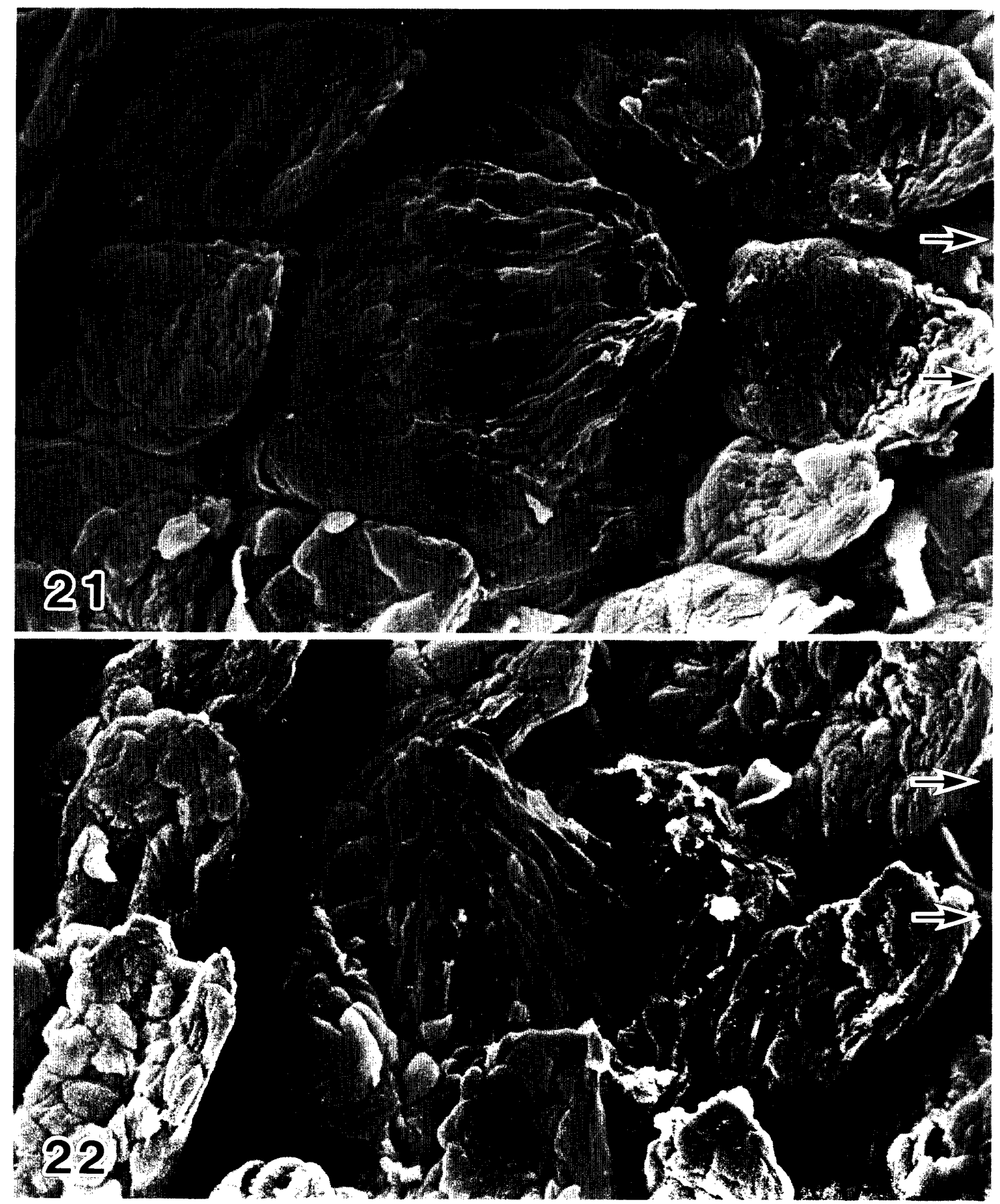

図21-22 神経切除 4 週閒後の苗状乳頭の走查電顕写真

図21乳頭背面中央部は咽頭側（知印）に向けて著しく突出する $\times 350$

図22 希にではあるが，咽頭側（矢印）とは巽なった方向に先端を傾斜する茸状乳頭も観祭される $\times 350$ 


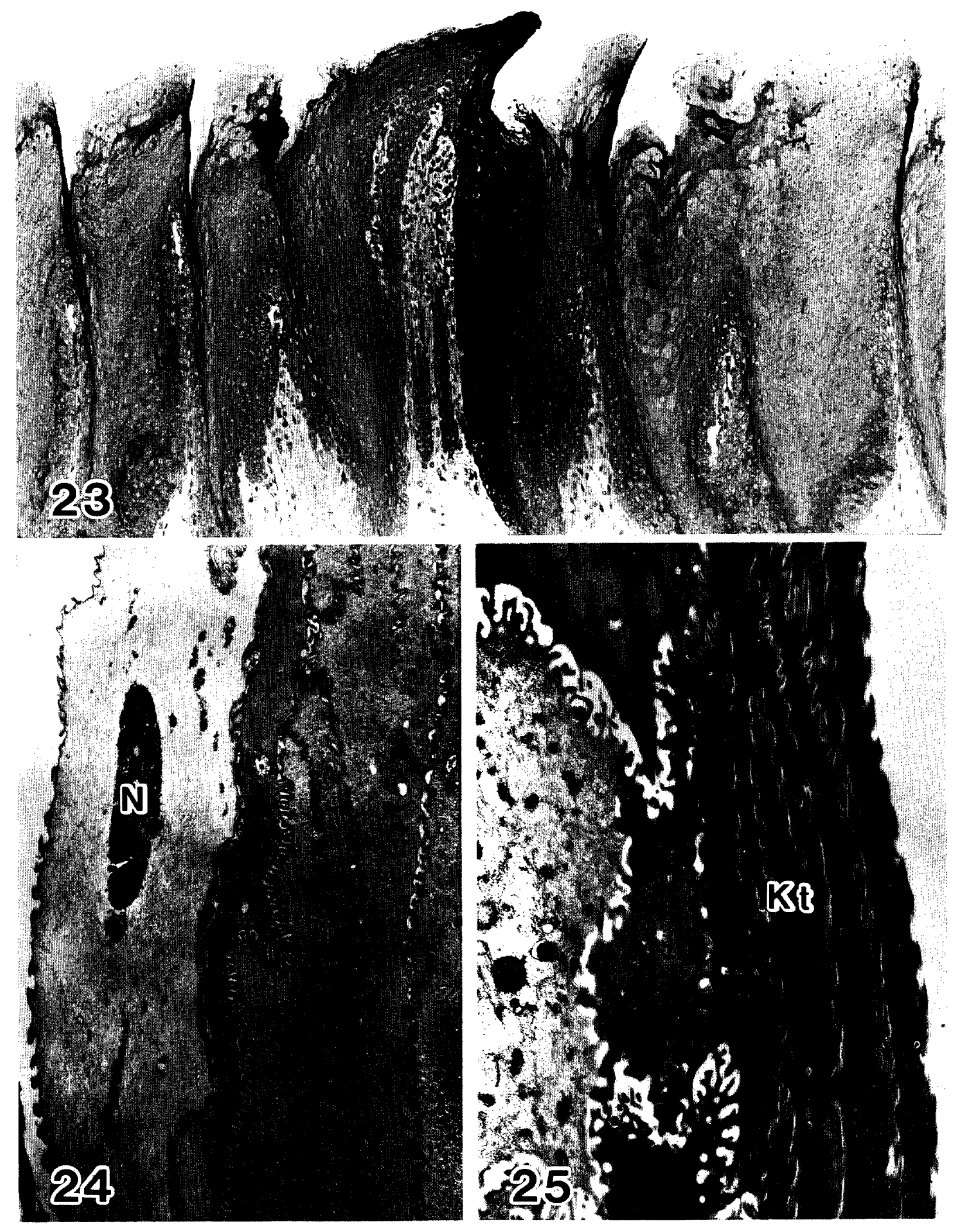

図23神経切除 4 週間後の茸状乳頭の矢状断光顕写真 $\times 180$

図24乳頭前面の透過電顕写真

最表層付近でも核（N）の残存する錯角化傾向を示す

$\times 4500$

図25 乳頭後面の透過電顕写真

電子密度の高い角質層 $(\mathrm{Kt})$ によって被われる $\times 7500$ 

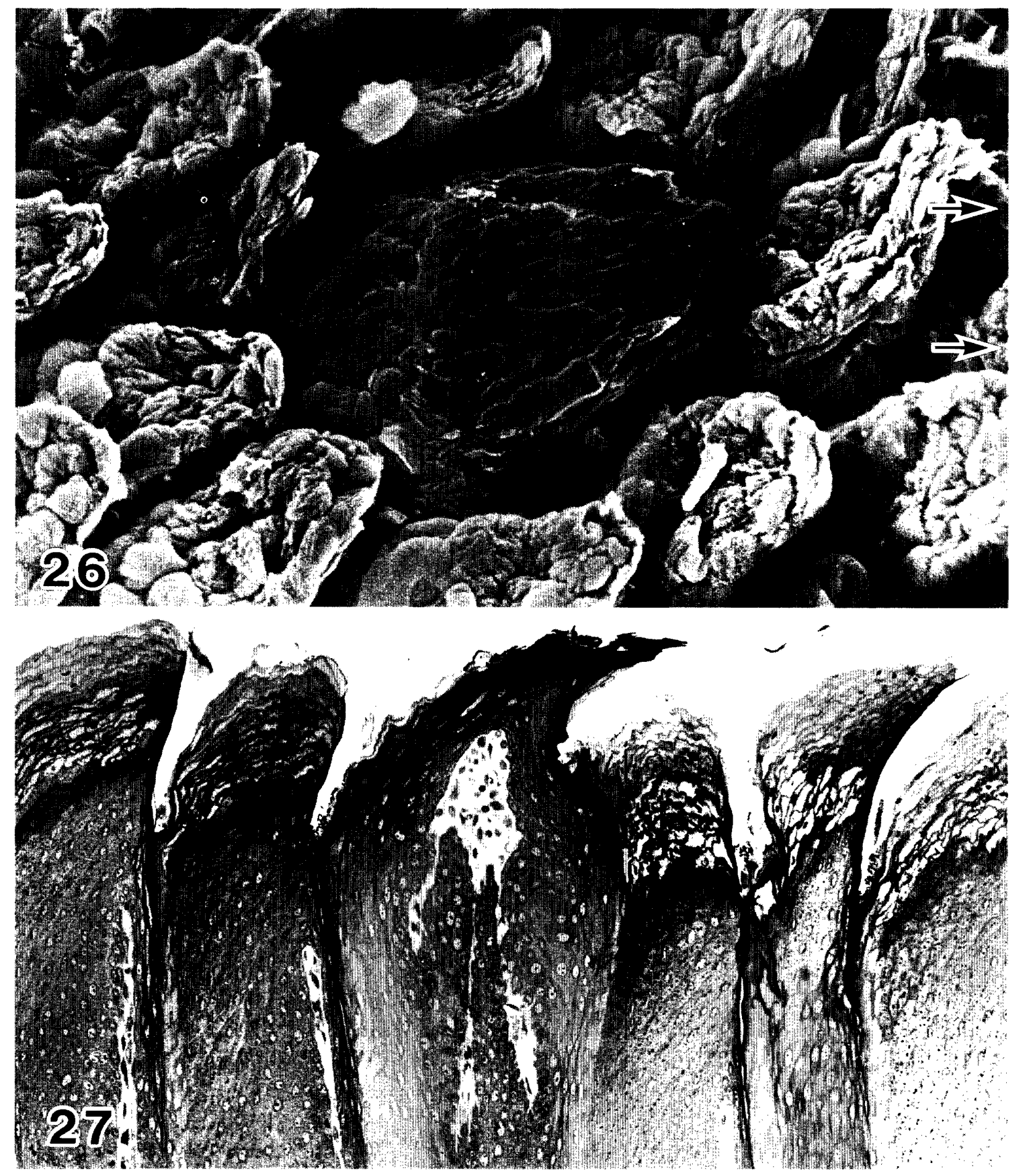

図26 神経切除 8 週間後の茸状乳頭の走查電顕写真

咽頭側（矢印）に傾斜した乳頭先端部はさらに尖鋭化する $\times 280$

図27 神経切除 8 週間後の茸状乳頭の矢状断光顕写真

角質層はさらに厚みを增し，乳頭後面部ではほぼ全域にわたって角質層により被われる $\times 250$ 

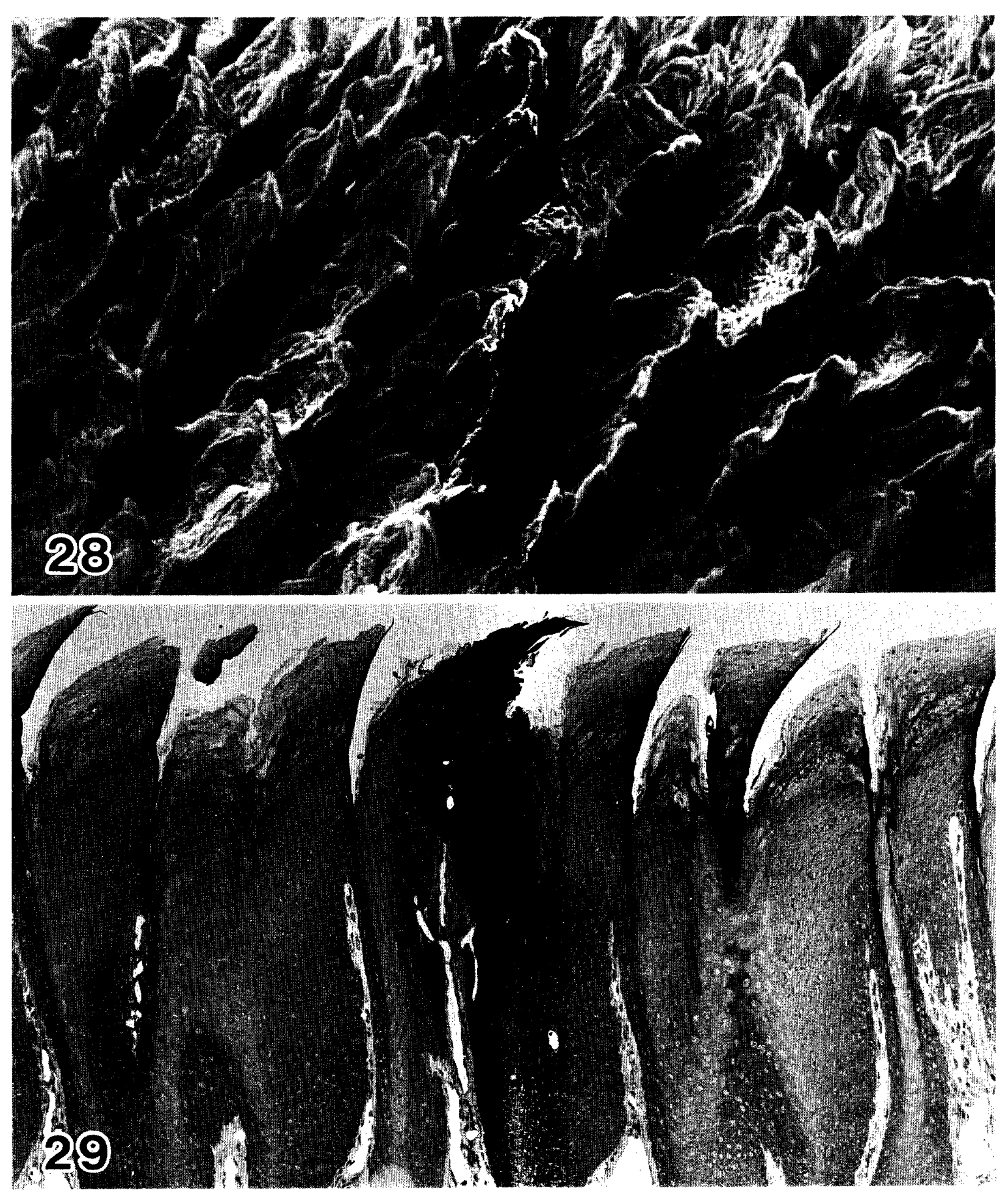

図28 神経切除 6 力月後の舌背前部走查電顕写真

舌背の広範囲にわたって茸状乳頭を確認することは出来ない $\times 170$

図29 神経切除 6 力月後の茸状乳頭の矢状断光顕写真

周囲系状乳頭と非常に類似した組織像を呈する $\times 170$ 

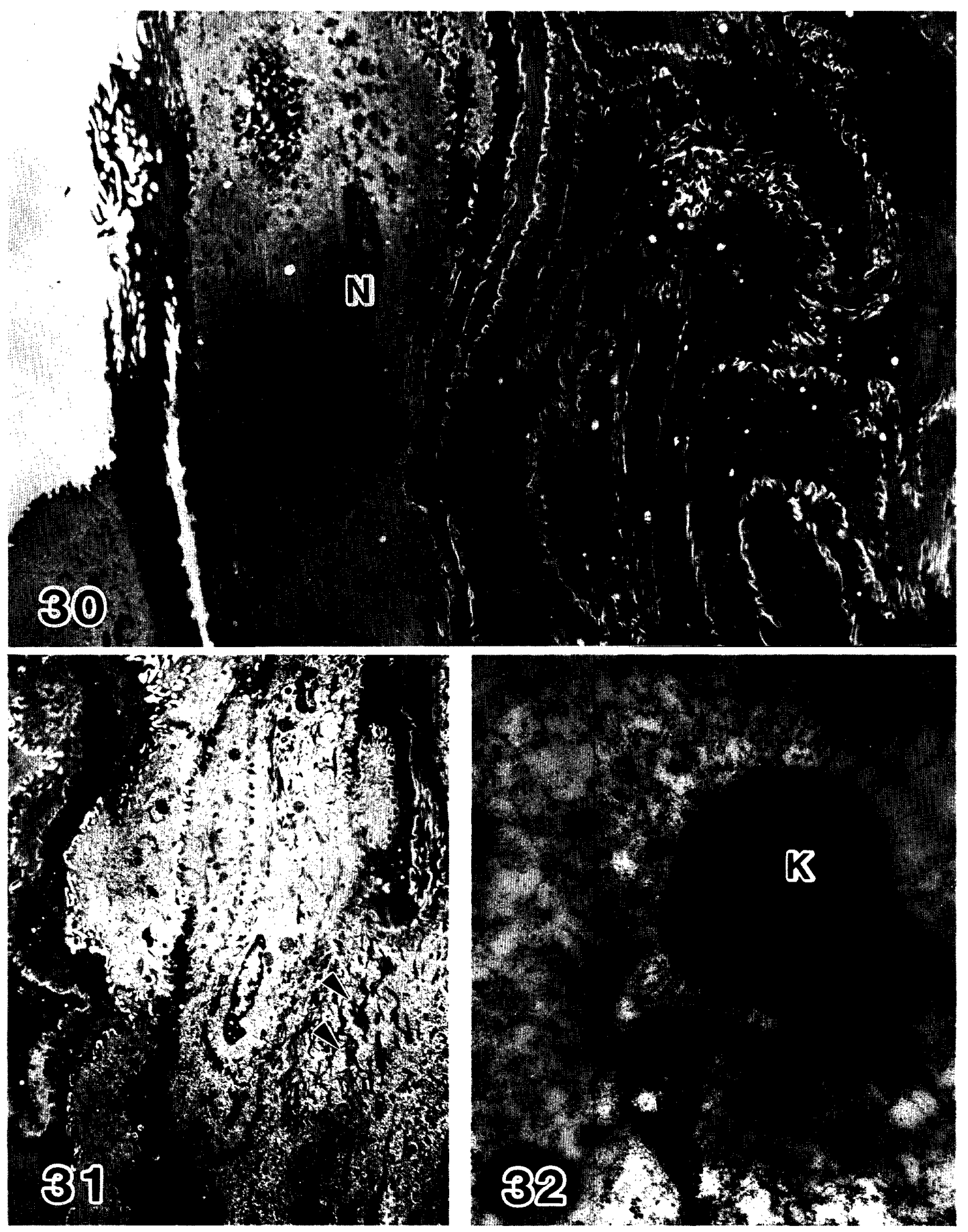

図30-32 神経切除 6 力月後の茸状乳頭前面の透過電顕写真

図30 表層付近まで核 $(\mathrm{N})$ の残存する錯角化傾向を示す $\times 3500$

図31 張原線維（矢じり）は細胞質内で集束せず散在している $\times 2500$

図32 ケラトヒアリン顆粒（K）の出現を認める $\times 25000$ 

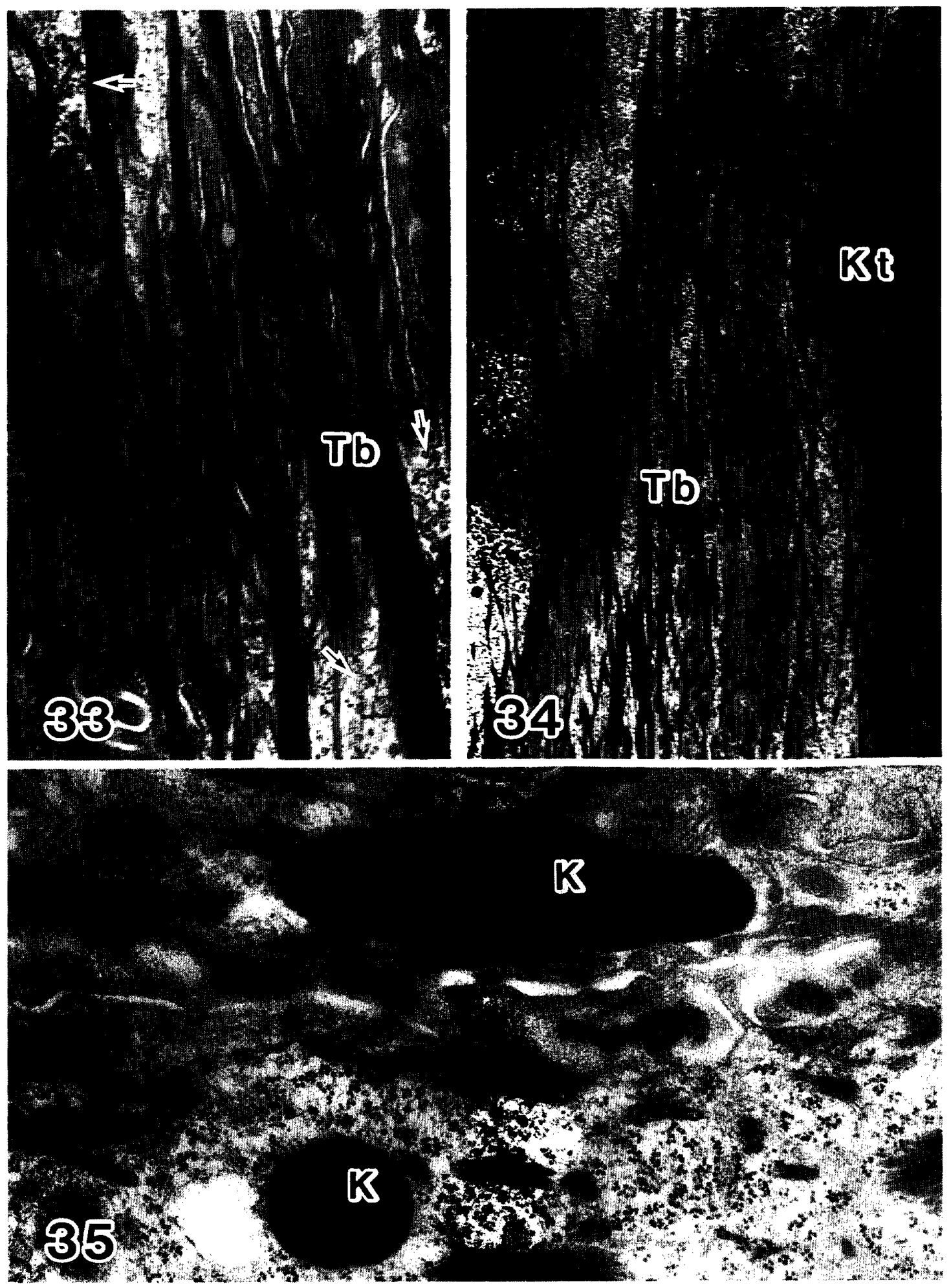

図33-35 神経切除 6力月後の茸状乳頭後面の透過電顕写真

図33＼cjkstart細胞質内は多数の張原線維（Tb）とりボゾーム（矢印）によって満たされている $\times 25000$

図34 張原線維（Tb）は扁平化した細胞の長軸に沿って並行な走行を示す

表層の角質細胞 $(\mathrm{Kt})$ は電子密度が高く，核 $(\mathrm{N})$ をはじめとした細胞内小器官は消失している $\times 5000$

図35 ケラトヒアリン顆粒（K）の出現を認める $\times 25000$ 
神経の再生にともなって味蕾も上皮内に再生することが

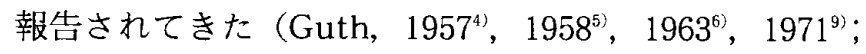
Fujimoto $ら, 1970^{8)}$; Kennedy, 1972(0); Oakley, $1974^{11)}$; 近藤ら，1983 ${ }^{122}$ )。 しかしながら茸状乳頭におい ては, 鼓索・舌神経を切除後も味蕾は消失しないとの報

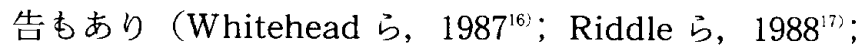

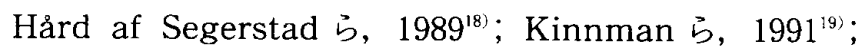

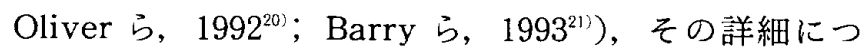
いては議論の多いところである.

Whitehead ら (1987) ${ }^{16\rangle}$ は，八ムスターを用いて鼓 索·舌神経切除後の咠状乳頭を透過電顕的に観察したと ころ, 神経切除によって, 実験側における電気生理学的 反纫が全く認められないにあ関わらず，ほとんどの乳頭 内に味蕾が存在することを報告した。 また Barry ら $(1993)^{21)}$ は, 同じくハムスターの鼓索・舌神経切除を 行い，味蕾細胞の標識酵素であるCa-ATPase を用いて 味蕾の変化を観察した。そその結果, ほとんどの茸状乳頭 内の味蕾に萎縮が認められるが，少なくとも 3 週間まで は, Ca-ATPase 活性を示す味蕾細胞が残存することを 報告した.

一方, Ganchrow ら (1989) 222) は幼若なラットで，ま た中島 $(1988)^{23)}$ ，Nakashima ら $(1990)^{24 〉}$ は成熟し たウサギで, 鼓索・舌神経を長期間にわたって切除した 状態にしておくと, 茸状乳頭の味蕾の多くは完全に消失 するのを観察した。 さらに味蕾の消失した茸状乳頭背面 の上皮に角化の異常な淮が起こるととあに, 糸状乳頭 様に先端が尖鋭化した乳頭に変化するのを報告した。 こ のような茸状乳頭にみられる同様の变化は, 成熟した ラットやスナネズミにす出現することが報告されている (Oakley ら, 199025).

今回の研究においても, 鼓索·舌神経を切除すると, 早期よりほとんどの味蕾は変性し，その一部は完全に消 失するとともに, 茸状乳頭が系状乳頭様に変化するのを 観察することができた。 また, 術後 6 力月を経過した舌 上皮では，走査電顕的にも系状乳頭之变化した茸状乳頭 を区別するのは困難で, 切片による観察によってのみ区 別することが可能であった。このように変化した茸状乳 頭を正常な糸状乳頭と微細構造的に比較検討したとこ ろ，いくつかの興味ある知見を得ることができた。

系状乳頭上皮の角化の様相に関しては, Farbman $(1970)^{377}$ がラットを用いて詳細に観察し報告してい る. その報告によると, 系状乳頭は乳頭内に深く入り込 んだ固有層の前面にみられる上皮細胞層と, 後面にみら れる上皮細胞層とでは, 角化の様相が著しく異なること
が示されている．すなわち，乳頭前面の上皮の角化様式 は，軟ケラチンと称される表皮などの角質層を形成する 角化様式に類似しており，ケラトヒアリン顆粒が多数分 布するが, 乳頭後面の上皮の角化様式は, 硬ケラチンと 称される角質層の形成を特徵とする角化様式に類似して いると述へている。

今回の観察では, ウサギの系状乳頭においてもラット におけるのと同様に, 乳頭の前面と後面とでは, 上皮細 胞層の角化様式が異なることを明らかにすることができ た，すなわち，乳頭の前面の上皮細胞層は，表層付近ま で核の残存する錯角化傾向を示し，ケラトヒアリン顆粒 が多数分布するのに対し，乳頭後面の上皮細胞層は，核 をはじめ細胞内小器官のほ上んどを消失した，厚い角質 層をとむなう真性角化を示すことを特徴としていた。

正常な系状乳頭の観察結果をむとに，系状乳頭様に変 化した茸状乳頭背面の上皮を観察したところ, 系状乳頭 上皮の角化の様相と類似したいくつかの組織学的特徽を 示す所見を観察することができた。

神経切除によって変化した茸状乳頭の背面上皮は, 系 状乳頭様に尖鋭化し，その先端を系状乳頭と同様に咽頭 方向へと傾斜させていた，さらにこのような極性は，神 経切除後経日的に著明となった。 また先端部付近では非 常に発達した角質層が認められた。これら角質層は，乳 頭の後面では連続的に上皮表層を被うのに対し, 前面で は広範讲におよぶ錯角化層へと移行していた。このよう な茸状乳頭後面上皮に出現した角質層は，系状乳頭後面 にみられる角質層に非常によく類似していた，系状乳頭 後面の角質層は，形態学的に毛皮質や爪の角質層に相当 する構造であるといわれている(Roth，1967 $7^{38}$ )。 また 藤田ら $(1981)^{399}$ は，系状乳頭後面部の角質層は，極め て強勒で剛性に富み, 系状乳頭に作用する外力に対し て, 後方から乳頭前面部を支える強力な支柱の役割を果 たしているのではないかと述べている，さらに Oakley ら $(1990)^{25}$ は, ラットやスナネズミで, 同様に茸状乳 頭の角化の六進之系状乳頭様変化を認めている. 彼ら は, 茸状乳頭が神経切除によって感覚感受を失う事によ り, 防御反沁が起こり, その結果乳頭背面の上皮に角化 の六進が出現したのではないかと推測した。.今回の研究 においても, 鼓索·舌神経を切除すると多くの茸状乳頭 は厚い角質層で被われた。このことは, 味蕾ならびに体 性感覚を失った茸状乳頭が様々な口腔環境に対して乳頭 を防御するための抵抗形態の表われであろうと考えられ た。

今回の観察で, 系状乳頭上皮の細胞質内には, 多数の 
ケラトヒアリン顆粒が出現するのが認められた. 一方, 茸状乳頭背面の上皮細胞には，透過電顕による観察にお いてもケラトヒアリン顆粒は認められなかった。しかし ながら神経切除後角化が方進し, 糸状乳頭様に变化した 茸状乳頭背面上皮細胞内に，しばしばケラトヒアリン顆 粒が出現するのが観察された。 ケラトヒアリン顆粒に は, 多数のリボゾームが周囲に付着している事が多く, リボゾームがその産生にあずかるのではないかと言われ ている (Suzuki ら，1972 ${ }^{40)}$ ). し汃し角化を示す表皮に あケラトヒアリン顆粒の出現しないこともあり，ケラト ヒアリン顆粒がケラチンの前駆物質であるのか否か, さ らには角化にとってその存在が必要であるのかさえ屯, まだよく理解されていない（藤田ら，1984 ${ }^{411}$ )。 Horstmann ら (1958) ${ }^{42)}$ はケラトヒアリン顆粒は急速に角化 を促進させ, その結果, 核の萎縮・消失を招来するので

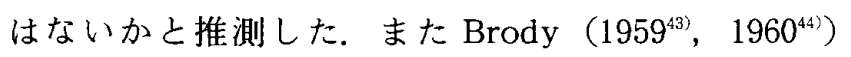
は，表皮ではケラトヒアリン顆粒がしばしば張原線維に 広範囲に沈着する, いわゆる “transitional cell” の段 階を経て角質層が形成される事を示唆し, 角化機構に重 要な役割を果たすのではないかと述べた，さらに Matoltsy ら (1970) ${ }^{45)}$ は生化学的分析により, ケラトヒア リン顆粒は硫黄を多く含む蛋白で, 角質の前段階物質で はないかと推測している. 今回, 角化の程度の低い正常 茸状乳頭上皮には認められなかったケラトヒアリン顆粒 が, 神経切除後の角化の亢進した茸状乳頭上皮内で認め られたことは，ケラトヒアリン顆粒が角質形成におい て，なんらかの役割を担っている可能性を示唆するすの と考えられる.

苜状乳頭の神経支配を切除すると, 味蕾が消失すると ともに, 乳頭背面の上皮の角化が六進し, 系状乳頭様に 尖鋭化した乳頭に変化するという結果については, 現在 までにいくつかの考察がなされてきたが，まだよく理解 されていない。

有郭乳頭や葉状乳頭において, 味神経（舌咽神経）を 切除すると, 味蕾が変性するとともに, 乳頭の萎縮や味 蕾が存在していた洪側壁上皮す菲薄になることが知られ ている (Guth, 1957); State ら, 1974(6)). さらに, 味 神経が再生するにつれて, 乳頭ならびに上皮はむとの形 態に回復し, 味蕾も再生する.このようなことから, 味 神経には味蕾で感受した情報を中枢に伝達する知覚神経 としての役割とともに, その支配領域の組織に対して神 経栄養的な役割を持つことが示唆されてきた（Guth, $1969^{47)}, 1971^{99}$; 長門, 1992 $2^{26)}$ ). 下等脊椎動物において

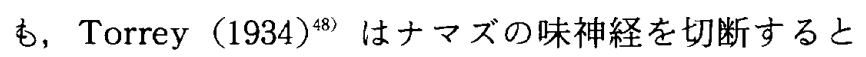

味蕾は変性するが, 神経の再生にともなって味蕾む再生 することから，神経体液学説 (neurohumoral theory) を提唱し, 神経に栄養的役割りがあることを述べた。し かしながら，その上うな役割を持つ物質について，多く の研究・推測がなされてきたが，今だに解明されていな いのが現状である.

Allara（1952) ${ }^{497}$ は去勢したラットにテストステロン を長期間投与すると, 有郭乳頭の背面上皮など本来味蕾 が出現しないような上皮に味蕾が出現するのを観察し た.ところが Zalewski (1969) ${ }^{50)}$ は，この結果を確認 する一方で, 舌咽神経を切除したラットにテストステロ ンを投与してお, 味蕾の変性消失が起こることや, 新た に味蕾が形成されることがないのを観察し，テストステ ロンが味蕾の形態維持に対して, 栄養効果を持つホルモ ンであることを否定した.

長門ら (1992 $)^{26)}$ は, 鼓索·舌神経切除を舌乳頭の 様々な発生分化過程の時期に行ったところ, 出生直後に おける神経切除が, 茸状乳頭の完全な系状乳頭化を引き 起こすのに対し, 生後 3 週以降の神経切除では, 糸状乳 頭様の外観を呈するには至るが，完全な糸状乳頭へは移 行しないという観察結果を報告している。このようなこ とから彼らは, 咠状乳頭が鼓索・舌神経の神経栄養因子 により, 特殊に形態変化した系状乳頭である可能性を示 唆した。

今回の観察で，糸状乳頭様に変化した茸状乳頭の中 に，しばしば尖鋭化した乳頭の先端が，様々な方向性を 示すものが認められた。同様の所見は，長門ら(1992 )$^{26)}$ 毛生後 3 週以降のラットで, 鼓索・舌神経切除を 行った研究において観察し，このように鼓索・舌神経に よる支配が断たれた後に，茸状乳頭が示す方向性の多様 さは, mechanoreceptor としての茸状乳頭に方向性が あることを示唆するあのと述べている.

Mackenzie ら (1984) $)^{511}$ は，煩粘膜上皮や口蓋粘膜 上皮を舌背の結合組織に移植した場合，移植された上皮 に糸状乳頭と類似した形態学的特徴を示す乳頭が形成さ れるのを観察した。彼らはこのような観察結果につい て, 胎生期ではよく知られている上皮之結合組織間の機 能的な相互関係が, 成体でも存在する可能性のあること を報告している。このように舌乳頭の発生·分化や上皮 組織の形態を維持する要因として，神経栄養的な因子だ けでなく, 結合組織そのむのからの直接的な因子のある 事も示唆されているが (Mackenzie ら, 19844); Mackenzie, 1984 $\left.{ }^{52}\right)$, その機構については現在までほとん ど理解されておらず, 将来解明しなければならない重要 
な課題であると考えられた。

\section{結論}

ウサギの苗状乳頭ならびに糸状乳頭の上皮について微 細構造的に観察を行った。ささらに鼓索・舌神経を切除し た後, 咠状乳頭背面上皮に出現する系状乳頭様变化を走 查電顕的に観察するとともに，变化した角化の様相を透 過電顕的に観察し，系状乳頭上皮と比較検討した。

茸状乳頭の表面形態は比較的平滑で，背面上皮の表層 はケラトヒアリン顆粒をともなわない菲薄な角質層で被 われていた，上皮細胞内にはデスモゾームと連続するよ く発達した張原線維が観察され, 各細胞はよく発達した 嵌合やデスモゾームによって，互いに結合するのが観察 された。

糸状乳頭では，乳頭の前面之後面の上皮細胞層におい て，角化の様相が著しく異なっていた，乳頭の前面で は，上皮細胞内にケラトヒアリン顆粒が多数出現すると ともに，最表層まで核を有する錯角化傾向の強い軟ヶラ チン層によって被われていた。 また張フィラメントは張 原線維を形成せず細胞質内に散在していた。一方, 乳頭 後面上皮の細胞質内は，リボゾームや張原線維に富む がケケラトヒアリン顆粒はほとんど認められなかった。 さらに表層になると核ならびに細胞内小器官は消失し， 真性角化を示す硬ヶラチン層によって被われていた。

鼓索・舌神経を切除すると, 茸状乳頭の味蕾は変性し 神経切除 1 週間後になると, 多くの咠状乳頭の背面上皮 に著しい角化の克進が出現するのか認められた。これら は乳頭背面の角質層が肥厚し, 糸状乳頭樣に先端が尖鋭 化するのを特徴としていた．この様な変化は経日ととも に著明となった．神経切除 4 週間後では，著しく尖鋭化 した乳頭背面中央部が，咽頭側に向かって系状乳頭様に 傾斜するのが観察された．神経切除後 8 週間経過する と, 茸状乳頭はさらに著しく糸状乳頭様に変化し， 6 力 月後では, 走查電顕的にも周囲の系状乳頭と区別するこ とが困難であった。

この様に変化の著しい 6 力月後の苗状乳頭背面上皮を 透過電顕的に観察する之, 乳頭の前面では所々に濃縮し た核の残存する錯角化層によって被われるが，乳頭後面 上皮表層では核や細胞内小器官が消失し, 角質層によ。 て被われていた。 また乳頭の前面执よび後面上皮の細胞 質内には，しばしばケラトヒアリン顆粒が出現するのが 観察され，系状乳頭上皮にみられるのと類似した角化の 二様性を示すことが, 微細構造的に明らかにされた。

鼓索·舌神経を切除すると, 茸状乳頭の多くが, 経日
とともに糸状乳頭と非常に類似した形態を示すように変 化したことは，咠状乳頭が鼓索・舌神経の支配によって 調節された特殊な糸状乳頭である可能性を示唆するもの と考えられた。

稿を終わるに臨み，本研究の機会を与えていただいた 恩師山田長敬名誉教授，御校閲を賜った恩師福田仁一教 授に深く感謝いたします。また，終始想切なる御指導， 御校閲を睗った本学口腔解剖学第 2 講座, 嶋村昭辰教授 ならびに豊島邦昭助教授に心から感謝の意を表します。 あわせて種々の御協力, 御指導をいただきました口腔外 科学第 1 講座亚びに口腔解剖学第 2 講座の諸先生方に深 謝いたします。

本論文の要旨の一部は, 第 53 回九州歯科学会総会 （平成 5 年5月 8 日）において発表した。

\section{引用文献}

1) von Vintschgau, M. und Honigschmid, J. : Nervus glossopharyngeus und Schmeckbecher. Arch. ges. Physiol. $14: 443-450,1877$.

2 ) Olmsted, J. M. D. : Effects of cutting the lingual nerve of the dog. J. Comp. Neurol. $33: 149-154,1921$.

3 ) Olmsted, J. M. D. : Taste fibers and the chorda tympani nerve. J. Comp. Neurol. $34: 337-341,1922$.

4) Guth, L. : The effect of glossopharyngeal nerve transection on the circumvallate papilla of the rat. Anat. Rec. 128:715-732, 1957.

5 ) Guth, L.: Taste buds on the cat's circumvallate papilla after reinnervation by glossopharyngeal, vagus and hypoglossal nerves. Anat. Rec. 130:25$37,1958$.

6) Guth, L. : Histological changes following partial denervation of the circumvallate papilla of the rat. Exp. Neurol. $8: 336-349,1963$.

7) Guth, L.: Degeneration and regeneration of taste buds. In : Handbook of sensory physiology, Vol. 4 (Ed. by Beidler, L. M.) Springer-Verlag, Berlin, 1971, $63-74$.

8 ) Farbman, A. I. : Fine structure of degenerating taste buds after denervation. J. Embryol. Exp. Morphol. $22: 55-68,1969$.

9) Fujimoto, S. and Murray, R. G. : Fine structure of degeneration and regeneration in denervated rabbit vallate taste buds. Anat. Rec. $168: 393-414,1970$.

10) Kennedy, J. G: The effects of transection of the glossopharyngeal nerve on the taste buds of the circumvallate papilla of the rat. Archs. Oral Biol. $17: 1197-1207,1972$. 
11) Oakley, B.: On the specification of taste neurons in the rat tongue. Brain Res. 75:85-96, 1974.

12）近藤 功, 久田太郎：マウスの変性および再生味蕾の組織 化学的研究一特にモ/アミン前駆物質の取り込みについて 一. 菌基礎誌 $25: 745-762,1983$.

13) Farbman, A. I. and Hellekant, G. : Quantitative analyses of the fiber population in rat chorda tympani nerves and fungiform papillae. Amer. J. Anat. 153: $509-522,1978$.

14) Zahm, D. S. and Munger, B. L. : The innervation of the primate fungiform papilla-Development, distribution and changes following selective ablation. Brain Res. Rev. $9: 147-186,1985$.

15) Whitehead, M. C., Beeman, C. S. and Kinsella, B. A. : Distribution of taste and general sensory nerve end ings in fungiform papillae of the hamster. Am. J. Anat. $173: 185-201,1985$.

16) Whitehead, M. C., Frank, M. E., Hettinger, T. P., Hou, L. - T. and Nah, H. -D. : Persistence of buds in denervated fungiform papillae. Brain Res. $405: 192-$ 195, 1987.

17) Riddle, D. R. and Oakley, B. : Partial neurotrophic maintenance of fungiform taste buds. Soc. Neurosci. Abstr. 14:768, 1988.

18) Hård af Segerstad, C., Hellekant, G. and Farbman, A. I. : Changes in number and morphology of taste buds in rats after transection of the chorda tympani or chorda-lingual nerve. Chem. Senses $14: 335-348$, 1989.

19) Kinnman, E. and Aldskogius, H.: The role of substance $\mathrm{P}$ and calcitonin gene-rerated peptide containing after a chronic chorda tympani nerve injury. Exp. Neurol. 113:85-91, 1991.

20) Oliver, S. D. and Whitehead, M. C. : Morphometry and cellular dynamics of denervated fungiform taste buds in the hamster. Chem. Senses $17: 529-542$, 1992.

21) Barry, M. A. and Savoy, L. D. : Persistence and calcium-depenent ATPase staining of denervated fungiform taste buds in the hamster. Archs oral Biol. 38 : $5-15,1993$.

22) Ganchrow, J. R. and Ganchrow, D. : Long-term effects of gustatory neurectomy on fungiform papillae in the young rat. Anat Rec. $225: 224-231,1989$.

23）中島 健：味神経切断, 吻合後の苗状乳頭ならびに味蕾の 变化に関する電子顕微鏡的研究. 九州歯会誌 $42: 991$ 1021, 1988.

24) Nakashima, T., Toyoshima, K., Shimamura, A. and Yamada, N. : Morphological chaneges of taste buds and fungiform papillae following long-term neurectomy. Brain Res. 553:321-323, 1990.

25) Oakley, B., Wu, L. - H., Lawton, A. and Desibour, C. : Neural control of ectopic filiform spines in adult tongue. Neuroscience $36: 831-838,1990$.

26）長門俊一, 谷岡博昭：鼓索・舌神経切除による苗状乳頭の 形態的変化. 口科誌 $41: 415-426,1992$.

27）長門俊一：神経のもう一つの働き“栄養的機能”につい て. 日本霜内療法協会雑誌 14（1）別冊，1993.

28) Millonig, G. : Advantages of a phosphate buffer for $\mathrm{OsO}_{4}$ solutions in fixation. J. Appl. Physics. $32: 1637$, 1961.

29) Luft, J. H. : Improvements in epoxy resin embedding methods. J. Biophys. Biochem. Cytol. $9: 409,1961$.

30) Björkman, N. : Low magnification electron micro scopy in histological work. Acta Morphol. Neerl. Scand. $4: 344-348,1962$.

31) Tandler, B.: Improved uranyl acetate staining for electron microscopy. J.Electron Microsc. Tech. 16:81 $-82,1990$.

32) Sato, T. : A modified method for lead staining of thin sections. J. Electron Microsc. 17:158-159, 1968.

33) Murakami, T. : A metal impregnation method of biological specimens for scanning electron microscopy. Arch. Histol. Jap. 35:323-326, 1973.

34) Inoue, T. and Osatake, H. : A new method of biological specimens for scanning electron microscopy: The t-butyl alcohol freeze-drying method. Arch. Histol. Cytol. 51 : No. $153-59,1988$.

35) Liem, R. S., van Willigen, J. D., Copray, J. C., Ter Hrost, G. J. : Corpuscular bodies in the palate of the rat. 2. Innervation and central projection. Acta Anat. $138: 65-74,1990$.

36）山本 隆, 志村 剛: 味覚情報の中枢処理. 神経進歩 $138: 788-797,1993$

37) Farbman, A. I. : The dual pattern of keratinization in filiform papillae on rat tongue. J. Anat. 106:233$242,1970$.

38) Roth, S. I. : Hair and nail. In : Ultrastructure of Normal and Abnormal Skin (ed. by Zelickson, A.) Lea and Febiger, Philadelphia, 1967, 105-131.

39）藤田浄秀, 小田島哲世：ハムスター口腔粘膜上皮における ケラトヒアリン顆粒の分布と形態の多彩性について．日ロ 外誌 $27: 1324-1328,1981$.

40) Suzuki, H. and Kurosumi, K. : Lamellar granules and keratohyalin granules in the epidermal keratinocyte$s$, with special reference to their origin, fate and function. J. Electron Microsc. $21: 285-292,1972$.

41）藤田恒夫, 藤田尚男 : 標準組織学各論. 第二版. 医学書 院, 東京, 1984，350-360.

42) Horstmann, E. und Knoop, A. : Elektronenmikroskopische Studien an der Epidermis. I. Rattenpfote. Z, Zellforsch. $47: 348-362$, 1958.

43) Brody, I. : An ultrastructural study on the role of the keratohyalin granules in the keratinization process. J. Ultrastruct. Res. 3 : $84-104,1959$.

44) Brody, I. : The ultrastructure of the tonofibrils in the 
keratinization process of normal human epidermis. J. Ultrastruct. Res. $4: 264-297,1960$.

45) Matoltsy, A. G. and Matoltsy, M. N. : The chemical nature of keratohyalin granules of the epidermis. J. Cell Biol. $47: 593-603,1970$.

46) State, F. A. and Bowden, R. M. : The effect of transection of the glossopharyngeal nerve upon the structure, cholinesterase activity and innervation of taste buds in rabbits. J. Anat. 118: $77-100,1974$.

47) Guth, L. : "Trophic" effects of vertebrate neurons. Neurosci. Res. Bull. $7: 1-73,1969$.

48) Torrey, T. M. : The relation of taste buds to their nerve fibers. J. Comp. Neurol. 59:203-220, 1934.

49) Allara, E. : Sullinfuluenza esercitata dagli ormoni sessuali sulla stuttura delle formazioni gastative di mus ruttus albinus. Riv. Biol. 44:209-229, 1952.

50) Zalewski, A. A. : Neurotrophic-hormonal interaction in the regulation of taste buds in the rat's vallate papilla. J. Neurobiol. 1 : $123-132,1969$.

51) Mackenzie, I. C. and Hill, M. W. : Connective tissue influences on patterns of epithelial architecture and keratinization in skin and oral mucosa of the adult mouse. Cell Tissue Res. 235: $551-559,1984$.

52) Mackenzie, I. C.: Epithelial-connective tissue relationships and the development and maintenance of structure. In: The structure and function of oral mucosa (Ed. by Meyer, J., Squier, C. A. and Gerson, S. J.). Pergamon, Oxford, 1984, 119-139. 